\title{
PENERAPAN METODE TSAQIFA DALAM PEMBELAJARAN AL QURAN DI RUMAH TAHSIN DESA GEGUTU KACANG KECAMATAN REMBIGA
}

\author{
Saprun 1, Mappanyompa 2, \\ 1. Program Studi PGMI, ${ }^{2}$ Program Studi KPI, Universitas Muhammadiyah Mataram, Indonesia \\ Ssaprun95@gmai.com ${ }^{1}$, myompakaltim@gmail.com $^{2}$
}

\begin{tabular}{l} 
INFO ARTIKEL \\
\hline Riwayat Artikel: \\
Diterima: $05-06-2020$ \\
Disetujui: 30-10 -2020 \\
\hline
\end{tabular}

\section{Kata Kunci:}

Pnerapan Metode Tsaqifa, Pembelajaran Al-Quran,

Rumah Tahsin,

\section{Keywords:}

Tsaqifa Method Implementation,

QuranIc Learning,

Tahsin House

\begin{abstract}
ABSTRAK
Abstrak: Metode tsaqifa memiliki keistimewaan dari metode yang lain, yaitu menjadikan peserta didik lebih mandiri, lebih aktif dan tidak membosankan didalam proses pembelajaran, artinya peserta didik menjadi lebih aktif didalam proses pembelajaran karena metode yang diberikan didalam buku ini menggunakan pola latihan-latihan kemandirian dan berkesinambungan. Penelitian yang penulis lakukan adalah penelitian lapangan (field research) yang pengumpulan datanya dilakukan secara langsung dari lokasi penelitian. Data-data penelitian ini diperoleh langsung dari rumah tahsin gegutu kacang kecamatan rembige dengan menggunakan observasi, wawancara, dan dokumentasi. Data-data yang dikumpulkan dianalisis dengan menggunakan teknik analisis interaktif Model Miles dan Huberman yang meliputi reduksi data, menyajikan data, hingga memverifikasi dan menyimpulkan data, selain itu juga peneliti menggunakan tindakan kelas (classroom Action Research). Hasil yang diharapakan dalam penelitian ini peneliti menemukan hasil yang bermanfaat untuk kepentingan lembaga rumah tahsin, peneliti berharap (1) Para peserta didik memiliki kemampuan membaca alQur'an dengan setandar bacaan yang baik dan benar berdasarkan aturan-aturan didalam membaca al-Quran. (2) Tercapainya target yang diharapkan yaitu mampu membaca sesuai dengan kaidah tajwid. (3) Menjadi tambaha refrensi dalam belajar mengajar al-Qur'an.
\end{abstract}

\section{A. LATAR BELAKANG}

Pendidikan adalah usaha sadar dan terencana untuk mewujudkan suasana belajar dan proses pembelajaran agar peserta didik secara aktif mengembangkan potensi dirinya untuk memiliki kekuatan spiritual keagamaan, pengendalian diri, kepribadian, kecerdasan, akhlak mulia, serta keterampilan yang di perlukan dirinya, masyarakat, bangsa, dan bernegara. Membaca AlQuran adalah kegiatan mendidik, mengajar, membimbing, dan melatih peserta didik belajar dalam peningkatan kompetensi. seperti yang disabdakan oleh Rosulullah:
"Sebaik-baik kamu adalah orang yang belajar AlQur'an dan mengajarkannya" (HR. Bukhari). Dinyatakan juga dalam hadis yang lain: "Belajarlah Al-Qur'an lalu bacalah. Sesungguhnya perumpamaan Al-qur'an bagi orang yang belajar, membaca, dan mengamalkannya, bagaikan wadah yang dipenuhi minyak kasturi yang semerbak baunya disetiap tempat". (HR. Tirmidzi.). ${ }^{1}$

Adapun dalam firman Allah, Artinya:

"Bacalah dengan (menyebut) nama Tuhanmu yang Menciptakan, Dia Telah menciptakan manusia 
dari segumpal darah. Bacalah, dan Tuhanmulah yang Maha pemurah, Yang mengajar (manusia) dengan perantaran kalamDia mengajar kepada manusia apa yang tidak diketahuinya." (Q.S. Al-Al alaq ayat $1-5)^{2}$

Pembelajaran Al-Quran yang optimal akan melahirkan generasi Qur'ani yang mampu memakmurkan bumi dengan Al-Qur'an dan menyelamatkan peradaban dunia dimasa mendatang. ${ }^{3}$ Syarat mutlak untuk memunculkan generasi Qur'ani adalah adanya pemahaman terhadap Al-Qur'an yang diawali dengan mampu membaca Al-Qur'an dengan baik dan benar sesuai dengan kaidah yang ditentukan.

Sabda Rasulullah Shallalahu 'alaihi wasallam:
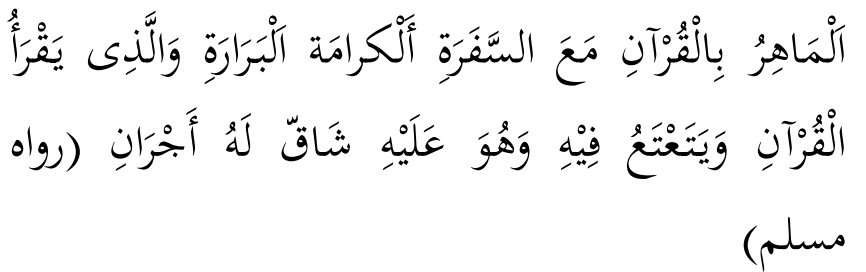

“Orang yang membaca al-Qur'an, lagi pula ia mahir, kelak mendapat tempat di dalam surga bersama dengan rasul-rasul yang mulia lagi baik, dan orang yang membaca al-Qur'an, tetapi tidak mahir. Membacanya tertegun-tegun dan tampak agak berat lidahnya (belum lancar), dia akan mendapatkan dua kali lipat pahala." (HR. Bukhari Muslim). ${ }^{4}$

Mempelajari al-Qur'an juga tidak lepas dari pengaruh keluarga, karena keluarga merupakan pengaruh pertama untuk memperoleh pendidikan di awal kepribadian anak di kemudian hari. Untuk menunjang keberhasilan pengajaran al-Qur'an tidak cukup diberikan di sekolah saja, oleh karena itu pihak orang tua sangat berperan dalam pendidikan. Orang tua atau dan masyarakat diharapkan dapat membantu Guru Pendidikan Agama Islam agar terjadi sinkronisasi antara pendidikan Agama Islam di sekolah, keluarga dan masyarakat, karena pembelajaran al-Qur'an sebagai suatu proses pengembangan potensi kreatifitas peserta didik yang bertujuan untuk mewujudkan manusia yang bertaqwa kepada Allah, dan bersifat cerdas, berbudi pekerti luhur, mandiri dan bertanggungjawab terhadap dirinya, serta agama. Dengan demikian seorang pendidik harus meningkatkan kualitas dalam pembelajaran agar potensi yang dimiliki peserta didik bisa berkembang dengan optimal.

${ }^{2}$ Bachtiar Surin, Terjemah \& Tafsir Al-Qur'an, (Bandung, Fa. SUMATRA, 1978). Hlm. 1438.

${ }^{3}$ Hayatun Fardah Rudi Arifin, “Belajar Al-QUr'an Strategis Siapkan Generasi Qur'ani" http://www.depag.co.id diakses pada tanggal 12 Februari 2013 Pukul 14.30 WIB.

${ }^{4}$ Muhammad Ali ash-Shabuny, Op. Cit., hlm. 10.
Kegiatan belajar mengajar merupakan inti dari pelaksanaan kurikulum, baik buruknya pendidikan atau mutu lulusan dipengaruhi oleh mutu kegiatan belajar mengajarnya. Bila mutu lulusannya bagus, dapat diprediksi bahwa mutu kegiatan belajar mengajarnya juga bagus atau sebaliknya, bila mutu belajar mengajarnya bagus, maka mutu lulusannya juga akan bagus. Proses pembelajaran al-Qur'an dengan menggunakan metode yang tepat akan mempermudah peserta untuk bisa membaca al-Qur'an dengan cepat. Salah satu penentu dalam kegiatan belajar mengajar a1Qur'an adalah metode.

Metode pembelajaran adalah suatu cara untuk menyajikan pesan pembelajaran sehingga pencapaian hasil pembelajaran dapat optimal. Dalam proses pembelajaran, metode memiliki kedudukan yang penting dalam upaya pencapaian tujuan pembelajaran. Tanpa metode, suatu pesan pembelajaran tidak akan dapat berproses secara efektif dalam kegiatan belajar mengajar kearah yang dicapai.

Pada dasarnya metode-metode yang ada sangat banyak dan mempunyai kelebihan dan kekurangan masing-masing, di antaranya: Menurut Mahmud Yunus dalam bukunya Metodik Khusus Bahasa Arab (Bahasa al-Quran), mengemukakan beberapa metode dalam belajar al-Quran seperti ${ }^{5}$ : al-barqi, Iqro, ummi dan masih banyak lagi metode-metode pembelajaran alQur'an yang ada dan terus berkembang, demikian juga motode pembelajaran al-Qur'an yang di terapkan di rumah tahsin yang ada di desa gegutu kecamatan rembige adalah metode yang diterapkan didalam pembelajaran al-Qur'an untuk peserta didiknya selama ini adalah metode Iqro, Rumah Tahsin ini berjalan selama 5 (lima) tahun dan sudah memiliki peserta didik 30 murid yang terdiri dari tingkat Sekolah Dasar (SD) sampai Sekolah Menengah Pertama (SMP).

Setelah peneliti mencoba melakukan wawancara dengan para pengajar dan mencoba mengevaluasi terhadap hasil pembelajaran baca alQur'an yang berjalan selama ini maka peneliti mendapatkan beberapa kendala diantaranya:

1. Kurangnya semangat peserta didik didalam belajar terlihat dari lebih banyak bermain dari pada belajar

2. Metode pembelajaran al-Qur'an yang monoton dan membosankan menjadikan peserta didik lebih cepat jenuh didalam belajar

3. Masih banyak peserta didik yang belum mampu membaca al-Qur'an dengan baik dan benar

${ }^{5}$ Mahmud Yunus, Metode Khusus Pendidikan Agama, (Jakarta: PT. Hidakaya Agung, 1975. hlm. 5 
Berangkat dari permasalahan diatas, peneliti mencoba memberikan solusi baru di dalam pembelajaran al-Qur'an dengan metode Tsaqifa, Yaitu sebuah metode yang mudah, praktis dan tidak membosankan dengan tempo waktu yang sangat singkat dan didesain khusus untuk anak yang belum bisa membaca al-Qur'an dengan baik dan benar. Hal itulah yang memotivasi peneliti untuk membuat penelitian dengan judul: Penerapan Metode Tsaqifa Dalam Pembelajar al-Qur'an di Rumah Tahsin desa Gegutu Kacang Kecamatan Rembiga.

\section{B. METODE PENELITIAN}

\section{Pendekatan dan Jenis Penelitian}

Pendekatan adalah perlakuan terhadap objek, sebagai sudut pandang etik, atau sebaliknya bagaimana seharusnya memperlakukan objek, sebagai sudut pandang emik. ${ }^{6}$ Maka pendekatan yang digunakan dalam penelitian ini adalah pendekatan kualitatif.

Salah satu karakteristik pendekatan kualitatif adalah deskriptif. Menurut Whitney (1960), penelitian deskriptif adalah penelitian yang mencari fakta dengan interpretasi yang tepat. $^{7}$

Jenis penelitian yang digunakan dalam penelitian ini adalah penelitian lapangan atau (field research) kualitatif. Alasan utama peneliti menggunakan pendekatan kualitatif dalam penelitian ini adalah karena metode ini lebih fleksibel dan bisa menyesuaikan diri dengan ragam kenyataan di lapangan.

\section{Kehadiran Penliti}

Penelitian kualitatif merupakan penelitian interpretatif, yang di dalamnya peneliti terlibat dalam pengalaman yang berkelanjutan dan terus menerus dengan para partisipan. Keterlibatan ini dalam proses penelitian kualitatif akan memunculkan serangkaian isu-isu strategis, etis dan personal. ${ }^{8}$

Kehadiran peneliti dalam penelitian kualitatif adalah sebagai "otak", "mesin" dan "instrumen" utama penelitian yang dapat memahami makna interaksi antar-manusia, membaca gerak muka, menyelami perasaan dan

\footnotetext{
${ }^{6}$ Andi Prastowo, Metode Penelitian Kualitatif Dalam Perspektif Rancangan Penelitian, (Yogyakarta: Ar-Ruzz Media, 2011), hlm. 181.

${ }^{7}$ Moh. Nazir, Metode Penelitian, (Bogor: Penerbit Ghalia Indonesia, 2014), cet. X, hlm. 43.

8 John W. Creswell, Research Design Pendekatan Kualitatif, Kuantitatif, dan MixTerj. Achmad Fawaid, (Yogyakarta: Pustaka Pelajar, 2010), hlm. 264.
}

nilai yang terkandung dalam ucapan atau perbuatan responden. ${ }^{9}$

Di tempat penelitian, peneliti hadir dengan melalui beberapa tahapan yaitu exploration, cooperation dan participation. ${ }^{10}$ Tahapan ini dilakukan untuk menyingkirkan dampak personal dan melindungi kejadian sosial di tempat penelitian dapat terjadi sealamiah mungkin dan seperti mana harusnya.

Dalam penelitian ini, peneliti akan hadir melakukan penelitian selama 2 bulan yaitu dimulai bulan Desember 2019 sampai dengan Mei 2020.

Untuk tahap exploration, peneliti akan mengexplore atau mencari tahu atau melakukan survei awal terhadap keberadaan lokasi tempat penelitian yaitu rumah tahsin al-Qur'an desa gegutu kacang. Tahap ini peneliti sedang peneliti lakukan sebagai langkah awal ketika penyusunan proposal penelitian.

Sedangkan pada tahap cooperation, peneliti akan menjalin kerjasama atau hubungan baik dan membangun keakraban dengan pihak-pihak rumah tahsin tersebut yang terpaut sebagai responden atau informan pada penelitian penerapan metode tsaqifa dalam pembelajaran Al-Qur"an.

Dan terakhir pada tahap participation, peneliti akan mengadakan partisipasi atau keikutsertaan terhadap fokus penelitian pada penelitian ini yaitu berupa keikut sertaan peneliti dalam pelaksanaan pembelajaran alQur"an metode tsaqifa yang sesuai dengan jadwal. Di rumah tahsin desa gegutu kacang, peneliti mengadakan partisipasi atau keikutsertaan pelaksanaan pembelajaran al-Qur"an metode tsaqifa pada kelompok pemula atau tingkat dasar.

\section{Penentuan Lokasi Penelitian}

Penelitian ini mengambil lokasi di dusun Gegutu Kacang kecamatan rembiga. Dipilihnya sebagai lokasi penelitian disebabkan karena beberapa alasan yaitu; pertama, peneliti mengasumsi semangat peserta didik didalam belajar al-Qur'an sangat tinggi dibandingkan dengan tempat-tempat pembelajaran al-Qur'an yang lain. Kedua, belum pernah ada peneliti yang melakukan penelitian di rumkah tahsin dusun gegutu kacang yang secara spesifik berkaitan tentang metode pembelajaran al-Qur'an dengan metode Tsaqifa. Ketiga, jangkauan peneliti dalam proses penelitian mudah dan bisa dijangkau karena lokasi penelitian masih berada di satu kota yaitu wilayah kota mataram.

\footnotetext{
${ }^{9}$ S. Nasution, Metode Penelitian Naturalistik Kualitatif, (Bandung: Tarsito, 2003), hlm. 9.

10 Sanapiah Faisal, Penelitian Kualitatif: Dasar-Dasar dan Aplikasi, (Malang: Yayasan Asah, Asih, Asuh 1989), hlm. 12.
} 


\section{Teknik Pengumpulan Data}

Pada penelitian ini, peneliti menggunakan beberapa teknik dalam mengumpulkan data yaitu teknik wawancara, teknik observasi dan teknik dokumentasi. Ketiga teknik tersebut akan penulis jelaskan di bawah ini:

\section{a. Observasi (Pengamatan)}

Observasi merupakan suatu prosedur mengumpulkan data dengan mengadakan pengamatan terhadap kegiatan yang sedang berlangsung dan mencatat hasil pengamatan secara sistematis di lapangan. ${ }^{11}$

Dan jenis observasi yang digunakan dalam penelitian ini adalah jenis observasi partisipan yaitu pengumpulan data melalui pengamatan terhadap objek pengamatan dengan langsung hidup bersama, merasakan serta berada dalam aktivitas kehidupan objek pengamatan. ${ }^{12}$

Maka dalam penelitian ini, peneliti akan mengamati dan mengikuti pelaksanaan pembelajaran al-Qur'an metode tsaqifa secara bersama-sama dari awal sampai akhir pembelajaran. Peneliti juga akan berusaha mengamati, menganalisis dan menyimpulkan maksud dari setiap tingkah laku dan perasaan yang terlihat oleh peneliti pada guru tsaqifa dan siswa dalam pembelajaran al-Qur"an metode tsaqifa tersebut.

Selain itu, peneliti juga akan mengadakan observasi terseleksi terhadap beberapa siswa yang dipilih secara acak berdasarkan tingkatan materi tsaqifa. Observasi terseleksi ini dilakukan untuk mengetahui tingkat atau prosentase dampak penerapan metode tsaqifa terhadap kemampuan membaca al-Qur"an siswa.

\section{b. Teknik Wawancara (Interview)}

Wawancara adalah cara menghimpun bahan keterangan yang dilaksanakan dengan mengadakan tanya jawab lisan secara sepihak, berhadapan muka, dan dengan arah serta tujuan yang telah ditentukan. Jenis metode wawancara yang digunakan dalam penelitian ini adalah metode wawancara secara mendalam dan terstruktur. Maka peneliti akan menggunakan pedoman wawancara (interview guide) dalam melakukan wawancara.

Adapun pihak-pihak yang akan diwawancarai oleh peneliti adalah koordinator tsaqifa dan guru tsaqifa desa gegutu kacang. Peneliti menggunakan metode wawancara ini

11 Nana Syaodih Sukmadinata, Metode Penelitian Pendidikan, (Bandung: Remaja Rosdakarya, 2006), hlm. 220.

12 Burhan Bungin, Penelitian Kualitatif; Komunikasi, Ekonomi, Kebijakan Public, Dan Ilmu Sosial Lainnya, Jakarta: Kencana Prenada Media Group, 2007), hlm. 116 untuk mendapatkan informasi tentang langkahlangkah guru dalam perencanaan pembelajaran al-Qur"an metode tsaqifa, strategi dalam pembelajaran al-Quran dengan metode tsaqifa, teknik guru dalam evaluasi pembelajaran alQur"an metode tsaqifa dan dampak penerapan metode tsaqifa terhadap kemampuan membaca alQur"an peserta didik.

Wawancara akan difokuskan pada entri point: (1) Bagaimana Proses Penyampaian Metode Pembelajaran Al-Qur'an Kepada Peserta Didik (2) Apa Saja Isi Materi Yang Disampaikan Dalam Metode Pembelajaran al-Qur'an di rumah tahsin.

\section{c. Teknik Dokumentasi}

Metode dokumentasi adalah suatu metode atau cara pengambilan data yang diperoleh di tempat penyimpanan dokumen. Dalam melaksanakan metode ini peneliti menyelidiki benda-benda, data yang tidak mungkin diperoleh dengan menggunakan interview dan observasi. ${ }^{37}$

Dokumentasi akan difokuskan pada entri point: (1) Bagaimana proses penyampaian metode pembelajaran al-Qur'an kepada peserta didik (2) Apa aaja isi materi yang disampaikan dalam metode pembelajaran al-Qur'an di rumah tahsin.

Studi dokumentasi yang peneliti lakukan adalah terutama pada dokumen resmi rumah tahsin. Dokumentasi ini peneliti jadikan landasan tentang keberadaan pembelajaran yang memiliki basis pendidikan Multikultural. Dokumentasi yang dikumpulkan juga peneliti manfaatkan untuk crosscheck data dari hasil pengamatan dan wawancara.

\section{Metode Analisis Data}

Data dalam penelitian kualitatif terbagi menjadi dua bentuk yaitu pertama, data yang diperoleh dalam bentuk kata-kata atau ucapan lisan (verbal) dan perilaku dari subjek (informan). Bentuk data yang pertama dalam penelitian ini adalah segala bentuk hasil wawancara dan observasi peneliti terhadap informan yang berkaitan dengan penerapan metode tsaqifa dan dampaknya terhadap kemampuan membaca alQur"an peserta didik. Kedua, data yang berasal dari dokumen-dokumen, foto-foto, dan benda-benda yang dapat digunakan sebagai pelengkap. Bentuk data yang kedua dalam penelitian ini adalah segala bentuk dokumen, foto dan benda yang diperoleh peneliti dari informan dan berkaitan dengan penerapan metode tsaqifa dalam pembelajaran alQur"an.

Sumber data dalam penelitian ini adalah pertama, sumber data primer yang mencakup

${ }^{37}$ Ahmad Anwar, MetodologiResearch(Yogyakarta: IRCisod, 1977), 
manusia sebagai subjek atau informan penelitian. Sumber data primer dalam penelitian ini adalah koordinator tsaqifa, guru tsaqifa dan peserta didik di rumah tahsin desa gegutu kacang. Dan peneliti akan memilih guru tsaqifa menjadi informan kunci karena guru tsaqifa merupakan perencana, pelaksana dan pengevaluasi hasil dari proses pembelajaran al-Qur"an metode tsaqifa. Kedua, sumber data sekunder yang berasal bukan dari manusia. Sumber data sekunder dalam penelitian ini adalah dokumen-dokumen yang relevan dengan fokus penelitian dan bersifat hard data (data keras), seperti gambar, foto dan catatan yang terkait dengan penerapan metode tsaqifa dalam pembelajaran al-Qur"an.

Dalam penelitian kualitatif terdapat juga objek penelitian. Objek penelitian adalah sasaran atau titik perhatian suatu penelitian. Adapun yang menjadi objek penelitian dalam penelitian ini adalah pertama, langkah-langkah guru dalam perencanaan pembelajaran al-Qur"an metode tsaqifa. Kedua, proses guru dalam pelaksanaan pembelajaran al-Qur"an metode tsaqifa. Ketiga, teknik guru dalam evaluasi pembelajaran AlQur"an metode tsaqifa. Dan yang keempat, dampak penerapan metode tsaqifa terhadap kemampuan membaca al-Qur"an siswa

\section{HASIL DAN PEMBAHASAN}

\section{a) Langkah-Langkah Guru Dalam Perencanaan Pembelajaran Al-Qur'an Metode Tsaqifa}

Sebelum melaksanakan suatu proses pembelajaran, guru harus menyusun perencanaan pembelajaran. Dalam perencanaan, guru akan menetapkan apa yang harus dilakukan dalam pembelajaran. Hal ini sebagaimana yang dijelaskan oleh Terry, bahwa perencanaan yaitu penetapan pekerjaan yang harus dilaksanakan oleh kelompok untuk mencapai tujuan yang telah ditentukan. ${ }^{13}$

Perencanaan merupakan kegiatan untuk menetapkan pekerjaan yang harus dilaksanakan dalam suatu kelompok demi meraih tujuan yang telah diputuskan. Begitu juga dengan perencanaan yang dilaksanakan dalam kelompok belajar alQur"an metode tsaqifa, guru tsaqifa harus menetapkan kegiatan-kegiatan atau ketentuanketentuan yang akan dilakukan untuk mencapai tujuan pembelajaran al-Qur"an metode tsaqifa.

Dengan ditetapkannya perencanaan dalam pembelajaran, semua kegiatan yang akan dilaksanakan dalam proses pembelajaran dapat tersusun dan terlaksana dengan baik, matang, terukur serta tidak diluar batas kendali guru.

13 Wina Sanjaya, Perencanaan dan Desain Sistem Pembelajaran hlm. 24-28.
Karena perencanaan tersebut merupakan acuan guru dalam melaksanakan kegiatan dalam proses pembelajaran.

Adapun menurut William H. Newman dalam Abdul Majid, menjelaskan bahwa: Perencanaan adalah menentukan apa yang dilakukan. Perencanaan mengandung rangkaian-rangkaian putusan yang luas dan penjelasan-penjelasan dari tujuan, penentuan kebijakan, penentuan program, penentuan metode- metode dan prosedur tertentu dan penentuan kegiatan berdasarkan jadwal sehari-hari. ${ }^{14}$

Perencanaan sebagai suatu langkah untuk menentukan apa yang akan dilakukan, terdiri dari rangkaian kegiatan penentuan kebijakan, penentuan program, penentuan metode dan penentuan prosedur suatu pekerjaan yang akan dilakukan. Jadi rangkaian-rangkaian kegiatan tersebut dirancang dan diputuskan menjadi suatu format atau bentuk perencanaan.

Demikian juga halnya dengan langkahlangkah perencanaan yang dilakukan guru tsaqifa dalam pembelajaran al-Qur"an dengan metode tsaqifa di rumah tahsin desa gegutu, yaitu terdiri dari kegiatan menentukan desain posisi pembelajaran, menentukan durasi pembelajaran, menentukan jumlah siswa dalam kelompok, menentukan model pembelajaran yang akan diterapkan dalam pembelajaran al-Qur"an metode tsaqifa.

Syaiful Bahri Djamarah mengungkapkan.15 bahwa beberapa hal yang perlu diatur sebagai langkah perencanaan guru dalam ruang kelas adalah:

1. Pengaturan tempat duduk yaitu posisi berhadapan, posisi setengah lingkaran dan posisi berbaris ke belakang.

2. Pengaturan alat-alat pengajaran terdiri dari perpustakaan kelas, alat peraga/media pembelajaran, papan tulis, kapur tulis dan papan presensi peserta didik.

3. Penataan keindahan dan kebersihan kelas terdiri dari hiasan dinding, penempatan lemari dan pemeliharaan kebersihan serta

4. Ventilasi dan tata cahaya

Hal diatas sebagaimana yang dilakukan guru tsaqifa dalam perencanaan pembelajaran al-Quran metode tsaqifa di rumah tahsin desa gegutu, terdapat kegiatan menentukan desain posisi pembelajaran atau pengaturan tempat duduk guru dan siswa. Bentuk pengaturan tempat duduk guru

\footnotetext{
14 Abdul Majid, Perencanaan Pembelajaran: Mengembangkan Standar Kompetensi Guru, (Bandung: PT. Remaja Rosdakarya, 2012), hlm. 15-16.

${ }^{15}$ Syaiful Bahri Djamarah, Guru dan Anak Didik Dalam Interaksi Edukatif, hlm. 175-177.
} 
dan siswa yang diterapkan di rumah tahsin ini adalah bentuk U. Dan pengaturan posisi alat-alat pengajaran seperti alat peraga tsaqifa berada tepat di belakang guru. Kedua pengaturan tersebut telah dirancang dan ditetapkan sebagaimana pilihan desain posisi pembelajaran yang direkomendasikan oleh metode tsaqifa.

Dan seperti yang diungkapkan oleh Conny Semiawan,16 bahwa beberapa hal-hal yang perlu diperhatikan guru dalam pengaturan ruang belajar yang termasuk langkah perencanaan pembelajaran yaitu:

1. kuran dan bentuk kelas.

2. Bentuk serta ukuran bangku dan meja peserta didik

3. Jumlah peserta didik dalam kelas.

4. Jumlah peserta didik dalam setiap kelompok

5. Jumlah kelompok dalam kelas dan

6. Komposisi peserta didik dalam kelompok (seperti peserta didik pandai dengan peserta didik kurang pandai, pria dengan wanita).

Begitu juga halnya dengan langkah-langkah yang direncanakan guru tsaqifa dalam pembelajaran al-Qur"an di rumah tahsin yaitu menentukan jumlah peserta didik dalam 1 kelompok yaitu sebanyak 3-10 anak. Kemudian model pengelolaan kelas yang digunakan oleh peserta didik dalam pembelajaran al-Qur"an dalam metode tsaqifa di rumah tahsin adalah model sorogan dengan penyesuaian ukuran ruang kelas.

\section{b) Proses Guru Dalam Pelaksanaan Pembelajaran Al-Qur'an Metode Tsaqifa}

Pada dasarnya, belajar mengajar merupakan suatu proses yang dilakukan secara sadar dan memiliki tujuan. Tujuan adalah sebagai pedoman ke arah mana akan dibawa proses belajar mengajar. Proses belajar mengajar akan berhasil bila hasilnya mampu membawa perubahan dalam pengetahuan, pemahaman, keterampilan dan nilai-sikap dalam diri peserta didik. ${ }^{17}$

Begitu juga halnya dengan pembelajaran alQur"an metode tsaqifa yang dilaksanakan, memiliki tujuan agar siswa dapat membaca alQur"an dengan baik dan benar dari bidang fashohah, makharijul huruf, tajwid, gharib dan lagu tartil yang telah ditetapkan pada metode tsaqifa.

Sebelum melaksanakan proses pembelajaran, guru perlu melakukan kegiatan mengelola kelas. Kegiatan mengelola kelas tersebut memiliki tujuan

${ }^{16}$ Conny Semiawan dkk, Pendekatan Keterampilan Proses, hlm. 64.

${ }^{17}$ Syaiful Bahri Djamarah, Guru Dan Anak Didik Dalam Interaksi Edukatif, hlm. 12. sebagaimana yang dikatakan oleh Zuldafrial adalah: 18

1. Mewujudkan situasi dan kondisi kelas yang memungkinkan peserta didik mengembangkan kemampuan secara optimal

2. Mempertahankan keadaan yang stabil dalam suasana kelas, sehingga bila terjadi gangguan dalam belajar mengajar dapat dieliminir.

3. Menghilangkan berbagai hambatan dan pelanggaran yang dapat merintangi terwujudnya interaksi belajar mengajar

4. Mengatur semua perlengkapan dan peralatan yang memungkinkan peserta didik belajar sesuai dengan lingkungan sosial, emosional dan intelektual peserta didik dalam kelas.

5. Melayani dan membimbing perbedaan individual peserta didik.

Adapun kegiatan mengelola kelas yang dilakukan guru tsaqifa dalam proses pembelajaran al-Qur"an metode tsaqifa di rumah tahsin, berdasarkan sub pembahasan yang sedang dipelajari siswa dan menggabungkan kelompok yang berdekatan. Sedangkan kegiatan mengelola kelas yang dilakukan dalam proses pembelajaran al-Qur"an metode tsaqifa di rumah tahsin, sesuai dengan pencapaian siswa pada masing-masing sub pembahsan materi dan pembagiannya secara random atau acak. Tetapi khusus untuk siswa kelas dasar atau pemula, pengelompokkannya berdasarkan hasil placement test

Dalam melaksanakan proses pembelajaran terdapat kegiatan awal, kegiatan inti dan kegiatan penutup. Kegiatan awal yang dilaksanakan guru dalam proses pembelajaran adalah membuka pelajaran dan melakukan apersepsi. Dalam melaksanakan kegiatan membuka pelajaran, guru harus memiliki keterampilan dalam melakukannya.

Demikian juga yang diungkapkan oleh Syaiful Bahri Djamarah, keterampilan membuka pelajaran adalah perbuatan guru untuk menciptakan siap mental dan menimbulkan perhatian anak didik agar terpusat pada apa yang akan dipelajari. Siasat membuka pelajaran bertujuan untuk menyiapkan mental peserta didik agar siap memasuki persoalan yang akan dipelajari atau dibicarakan, menimbulkan minat serta pemusatan anak didik pada apa yang akan dibicarakan dalam kegiatan interaksi edukatif. ${ }^{19}$

Adapun kegiatan membuka pelajaran yang dilakukan guru tsaqifa dalam proses pembelajaran al-Qur"an metode tsaqifa yaitu mengucapkan

${ }^{18}$ Zuldafrial, Strategi Belajar Mengajar, (Pontianak: UIN Press Pontianak, 2012), hlm.85-86

${ }^{19}$ Syaiful Bahri Djamarah, Guru Dan Anak Didik Dalam Interaksi Edukatif, hlm. 138-139. 
salam pembuka dan membaca do"a sebelum belajar al-Qur"an secara bersama-sama. Do"a yang akan dibaca sudah tertulis dalam modul mengajar guru tsaqifa. Kemudian guru akan melakukan apersepsi yaitu membaca ulang materi yang dipelajari kemarin secara bersama-sama.

Dalam proses pelaksanaan pembelajaran disarankan adanya penggunaan media pembelajaran. Media pembelajaran ini dapat berupa media cetak ataupun non cetak. Intinya media pembelajaran yang digunakan tersebut merupakan alat peraga yang dapat dilihat, disentuh dan dirasa oleh siswa.

Fungsi penggunaan media dalam pembelajaran adalah hal-hal bersifat abstrak bisa dikongkritkan dan hal-hal yang terlalu besar bisa dikecilkan dan sebaliknya. ${ }^{20}$ Dan menurut Arsyad, semakin banyak alat indra yang digunakan untuk menerima dan mengolah informasi, maka semakin banyak materi pelajaran yang dapat dimengerti dan dipertahankan dalam ingatan.

Berkaitan dengan pernyataan diatas, guru tsaqifa di rumah tahsin juga menggunakan media pembelajaran dalam proses pelaksanaan pembelajaran al-Qur"an metode tsaqifa, jika media pembelajaran belum selesai dibaca bersama-sama. Cara guru menggunakan media pembelajaran adalah dengan membaca materi pada alat peraga tsaqifa dan diikuti seluruh murid. Setelah itu guru menunjuk murid satu per satu untuk membaca materi pada alat peraga dan disimak oleh murid yang lain (jika waktunya memadai). Alat peraga yang digunakan guru dalam pembelajaran alQur"an metode tsaqifa yaitu berupa kumpulan materi pada buku ajar tsaqifa brupa buku khusus untuk memperagakan metode tsaqifa.

\section{c) Teknik Guru Dalam Evaluasi Pembelajaran Al-Qur'an Metode Tsaqifa}

Dalam proses pembelajaran perlu dilaksanakan evaluasi atau tes atau ujian hasil belajar. Evaluasi ini dilaksanakan gunanya untuk mengetahui batas pemahaman atau kemampuan siswa terhadap suatu materi pelajaran. Hal ini senada dengan yang diungkapkan oleh Mulyadi, bahwa manfaat hasil ujian bagi peserta didik adalah. ${ }^{21}$

1. Dapat mengetahui apakah ia sudah mengetahui bahan yang disajikan oleh guru

2. Dapat mengetahui bagian mana yang belum dikuasainya sehingga ia berusaha untuk

${ }^{20}$ Azhar Arsyad, Media Pembelajaran, (Jakarta: PT. Raja Grafindo Persada, 2008), hlm. 9.

${ }^{21}$ Mulyadi, Evaluasi Pendidikan: Pengembangan Model Evaluasi Pendidikan Agama Di Sekolah, (Malang: UIN Maliki Press, 2010), hlm. 168. mempelajarinya sebagai upaya perbaikan.

3. Dapat merupakan penguatan bagi murid yang sudah memperoleh skor tinggi.

4. Dapat merupakan diagnosa bagi murid yang bersangkutan ia mengetahui bagian yang sukar untuk dikuasainya.

Begitu juga halnya dengan evaluasi yang dilaksanakan guru tsaqifa dalam pembelajaran alQur"an metode tsaqifa di rumah tahsin memiliki tujuan untuk mengetahui apakah siswa sudah dapat memahami materi yang diajarkan guru. Dan hasil evaluasi tersebut akan menjadi sebab guru untuk meminta siswa melanjutkan atau mengulangi bacaannya pada halaman buku panduan yang dipelajari.

Evaluasi dapat dilaksanakan langsung setiap akhir pembelajaran atau setiap kurun waktu tertentu dalam proses pembelajaran. Hal ini senada dengan yang diungkapkan Suharsimi Arikunto ${ }^{22}$, bahwa evaluasi yang dilaksanakan dalam proses pembelajaran terdiri dari 3 bentuk evaluasi yaitu sebagai berikut:

1. Tes formatif adalah penilaian yang digunakan untuk mengukur satu atau beberapa pokok bahasan tertentu dan bertujuan untuk memperoleh gambaran tentang daya serap siswa terhadap pokok bahasan tersebut.

2. Tes subsumatif adalah penilaian yang meliputi sejumlah bahan pengajaran dalam waktu tertentu.

3. Tes sumatif adalah penilaian yang diadakan untuk mengukur daya serap siswa terhadap bahan pokok-pokok bahasan yang telah diajarkan selama satu semester, satu atau dua tahun pelajaran.

Demikian juga halnya dengan evaluasi yang dilaksanakan guru tsaqifa dalam pembelajaran alQur"an metode tsqifa di rumah tahsin terdiri dari 3 bentuk evaluasi yaitu sebagai berikut:

1. Evaluasi yang dilaksanakan guru tsqifa kepada siswa ketika akhir pertemuan dalam pembelajaran al-Qur"an metode tsqifa. Evaluasi ini dilaksanakan dengan tujuan untuk melihat kemampuan siswa bisa naik atau tidak ke halaman selanjutnya pada jilid buku tsqifa yang dipelajarinya.

Hasil yang diperoleh siswa dalam evaluasi ini akan ditulis di buku prestasi tsaqifasiswa dan jurnal. Sebagaimana yang diketahui bahwa jurnal merupakan catatan pendidik di dalam dan di luar kelas yang berisi informasi hasil pengamatan tentang kekuatan dan kelemahan peserta didik yang berkaitan dengan sikap dan perilaku. ${ }^{122}$

${ }^{22}$ Suharsimi Arikunto, Dasar-Dasar Evaluasi Pendidikan, hlm. 36- 
Hal diatas sesuai dengan apa yang dilakukan guru tsaqifa dalam evaluasi pembelajaran al-Qur"an metode ti di rumah tahsin, bahwa hasil evaluasi siswa setiap akhir pertemuan dalam pembelajaran al-Qur"an metode tsaqifa akan ditulis di buku prestasi tsaqifa siswa dan jurnal mengajar yang diberikan koordinator tsaqifa setiap bulan.

2. Evaluasi yang dilaksanakan guru tsaqifa kepada siswa ketika akan naik pembahasan yang sedang dipelajarinya. Evaluasi ini dilaksanakan dengan tujuan untuk melihat kemampuan siswa bisa naik atau tidak ke pebahasa berikutnya selanjutnya

3. Evaluasi yang dilaksanakan oleh koordinator tsaqifa kabupaten atau kota setempat kepada siswa ketika akhir seluruh pembelajaran AlQur"an metode tsaqifa. Evaluasi ini dilaksanakan dengan tujuan untuk menentukan kelulusan siswa dalam pembelajaran al-Qur"an dengan metode tsaqifa. Dalam evaluasi akhir ini terdapat 2 bentuk evaluasi yaitu:

a. Munaqasyah

1. Bahan yang akan diujikan dalam evaluasi munaqasyah ini adalah:

2. Fashahah dan tartil Al-Qur"an (juz 1-30).

3. Membaca gharib dan penjelasannya

4. Teori ilmu tajwid dan menguraikan hukumhukum bacaan dan

5. Hafalan dari surat Al-A"la sampai surat AnNaas. metode tsaqifa

b. Khataman dan imtihan

Khataman dan imtihan merupakan bentuk evaluasi yang melibatkan publik. Kegiatan ini melibatkan seluruh stakeholder sekaligus merupakan laporan secara langsung kualitas hasil pembelajaran al- Qur"an metode tsaqifa kepada orang tua wali santri/masyarakat. Kegiatan evaluasi ini meliputi:

1. Demo kemampuan membaca dan hafalan alQur"an.

2. Uji publik kemampuan membaca, hafalan, bacaan gharib dan tajwid dasar serta

3. Uji dari tenaga ahli al-Qur"an dari tim tsaqifa dengan lingkup materi tertentu

\section{d) Dampak Penerapan Metode Tsaqifa Terhadap Kemampuan Membaca Al-Qur'an Siswa}

Suatu kegiatan pembelajaran dikatakan berhasil jika dapat terlaksana dan tercapai seluruh tujuan pembelajaran dengan baik. Dan dikatakan juga bahwa suatu proses pembelajaran dikatakan berhasil, apabila memiliki dampak atau perubahan yang penting dan terlihat dalam diri peserta didik setelah proses pembelajaran tersebut. Dampak atau perubahan setelah proses pembelajaran tersebut dapat dilihat dari tolak ukur atau parameter yang dirumuskan dalam pembelajaran.

Dan yang menjadi tolak ukur keberhasilan suatu proses pembelajaran adalah: ${ }^{23}$

1. Daya serap terhadap bahan pembelajaran yang diajarkan mencapai prestasi tinggi, baik secara individual maupun kelompok.

2. Perilaku yang digariskan dalam tujuan pembelajaran telah dicapai oleh siswa, baik secara individual maupun kelompok.

Sebagaimana juga dampak penerapan metode tsaqifa yang terlihat di rumah tahsin adalah:

1. Daya serap siswa terhadap materi pelajaran alQur"an metode tsaqifa adalah cepat.

2. Perilaku yang digariskan dalam tujuan pembelajaran yaitu siswa menjadi lebih memahami cara mengucapkan huruf hijaiyah sesuai dengan makharijul huruf, tajwid, gharib serta lagu siswa dalam membaca al-Qur"an menjadi lebih tertata.

\section{SIMPULAN DAN SARAN}

\section{A. SIMPULAN}

Berdasarkan paparan data, hasil penelitian dan pembahasan hasil penelitian pada bab-bab sebelumnya. Maka simpulan dari penelitian ini adalah sebagai berikut:

1. Langkah-langkah guru dalam perencanaan pembelajaran al-Qur"an metode tsaqifa berpedoman pada aturan-aturan yang telah ditetapkan oleh guru tsaqifa seperti menentukan durasi pembelajaran dan desain posisi pembelajaran. Maka dapat dikatakan bahwa ketentuan-ketentuan yang telah disusun guru tsaqifa dalam perencanaan pembelajaran, tidak terlepas dari ketentuan baku metode tsaqifa.

2. Proses guru dalam pelaksanaan pembelajaran al-Qur"an metode tsaqifa merujuk kepada tahapan pembelajaran yang telah ditetapkan dalam buku tsaqifa dan ditambah sedikit variasi pada proses pelaksanaan. Tahapan pembelajaran tersebut terdiri dari beberapa bagian yaitu pembukaan, apersepsi, penanaman konsep, pemahaman konsep, latihan/keterampilan kemandirian, evaluasi dan penutup.

3. Teknik guru dalam evaluasi pembelajaran al-Quran metode tsaqifa mengacu kepada

\footnotetext{
${ }^{23}$ Syaiful Bahri Djamarah dan Aswan Zain, Strategi Belajar Mengajar, hlm. 106.
} 
teknik evaluasi yang telah ditetapkan dala buku metode tsaqifa

4. Penerapan metode tsaqifa yang dilakukan guru dalam pembelajaran al-Qur"an sangat berdampak baik terhadap kemampuan membaca al-Qur"an peserta didik. Hal ini dapat dilihat dari daya serap dan perilaku pese rta didik yang tampak setelah pelaksanaan proses pembelajaran al-Qur"an.

\section{B. SARAN}

Berdasarkan uraian dalam penelitian ini, ada beberapa saran yang peneliti dapat ajukan kepada beberapa pihak yang diharapkan dapat menjadi masukan dalam penelitian selanjutnya. Diantaranya adalah:

1. Guru tsaqifa sebaiknya mengikuti aturan dalam pembelajaran al- Qur'an metode tsaqifa yang telah ditetapkan pada buku ajar seperti kelengkapan dan penggunaan media pembelajaran, pengadaan lembar jurnal dan rekapitulasi bulanan dalam pembelajaran, penyesuaian durasi pembelajaran yaitu selama1 jam.

2. Guru tsaqifa sebaiknya melaksanakan tahapan pembelajaran al-Qur"an konsisten dengan metode yang ada pada buku ajar tsaqifa.

3. Kepada peneliti selanjutnya hendaknya mengembangkan penelitian ini dengan melakukan penelitian yang lebih luas dan mendalam.

\section{DAFTAR RUJUKAN}

Azra, Azumardi Identitas dan Krisis Budaya, Membangun Multikulturalisme Indonesia, From http:/budpar.go.id/agenda/precong ress /makalah/abstrak /58 \% 20 azra.htm, akses 10 Januari 2008, jam 11.00

Banks, James, 2000, Teaching Strategies For the Social Studies: Inquiry, Valuing, and Decision Making, Philippines: Addison-Wesley.

Dawam, Ainurrofiq, 2003, "EMOH" Sekolah: Menolak "Komersialisasi Pendidikan" dan "Kanibalisme Intelektual" menuju Pendidikan Multikultural, Yogyakarta: Inspeal Ahimsakarya Press.

Mappanyompa. (2019). Pengaruh Pendidikan Kemuhammadiyahan Terhadap Sikap Perilaku Siswa, Ibtida'iy Journal PGMI, 4 (1),17-29

Hikam, M. A. (2015). Peran Kepemimpinan Visioner Dalam Rangka Menanggulangi Ancaman

Eliade, Mircea, 2001, "Realitas Sakral”, dalam Danie L. Pals, Seven Theories of Religion: Dari Animisme E.B Taylor, Materialisme Karl Marx,
Hingga Antropologi Budaya C. Geertz, Alih Bahasa Noer Zaman, Jogyakarta: Qalam.

Harjanto, Nico T., 2002, "Antara Kebangsaan dan Kwarganegaraan" dalam Indra J. Piliangdkk., MerumuskanKembaliKebangsaan Indonesia, Jakarta: CSIS.

Kuntowijoyo, 2003, "Malin Kundang, Jangan Jadi Lebai Malang: Muhammadiyah dan Budaya Lokal", dalam Amin Abdullah, Agama dan Pluralitas Budaya Lokal, Surakarta: Universitas Muhammadiyah Press

Maslikhah, 2007, Quo Vadis Pendidikan Multikultural: Reconstruksi Sistem Pendidikan berbasis Kebangsaan, Surabaya: JP Books.

Margono, S, 2005, Metodologi Penelitian Pendidikan, Jakarta: Rineka Cipta.

Miharja, Achdiat, M., 1977, Polemik Kebudayaan, Jakarta: Pustaka Jaya.

Naim, Ngainun dan Achmad Sauqi, 2008, Pendidikan Multikultural: Konsep dan Aplikasi, Jogyakarta: Ar-Ruzz Media.

Nasution, S., 2006, Metode Reasearch (Penelitian Ilmiah), Jakarta: Bumi Aksara.

Padil, Moh dan Triyo Supriyanto, 2007, Sosiologi Pendidikan, Malang: UIN Malang Press.

Peursen, Van, 1985, Strategi Kebudayaan, alih bahasa Dick Hartono, Jogjakarta: Kanisius.

Farris, P.J., \& Cooper, S. M. 1994, Elementary Social Studies; a Whole Language Approach. Lowa: Brown \& Benchmark Publisher.

Savage, T.V. \& Amstrong, D.G, 1996, Effective Teaching in Elementary Social Studies, Ohio: Prentice Hall.

Yunus, Firdaus, M., 2007, Pendidikan Berbasis Realitas Sosial, Jogyakarta: Logung Pustaka.

Undang-undang RI. No. 20 Tentang Sistem Pendidikan Nasional, 2006, Bandung: CV Nuansa Aulia

Woodward, Mark R., 2004, Islam Jawa, alih bahasa Hairus Salim, Jogjakarta: LKiS.

Zaini, Hisyam, dkk, 2008, Strategi Pembelajaran aktif, Jogjakarta: Pustaka Insan Madani.

Akhmad Syarufuddin, Mendidik Anak Membaca, Menulis Dan Mencintai Al-Qur'an, (Jakarta. Gema Insani, 2004). 